KAMILA KACPRZAK

Uniwersytet Kazimierza Wielkiego

w Bydgoszczy

\title{
ZWIĄZKI UCZUCIOWE ADOLESCENTÓW W PERSPEKTYWIE ROZWOJOWEJ - PRZEGLĄD WYNIKÓW BADAŃ
}

\begin{abstract}
Kacprzak Kamila, Związki uczuciowe adolescentów w perspektywie rozwojowej - przegląd wyników badań [Adolescents' Romantic Relationships in the Developmental Perspective - Research Review]. Studia Edukacyjne nr 36, 2015, Poznań 2015, pp. 179-203. Adam Mickiewicz University Press. ISBN 978-83-232-2958-2. ISSN 1233-6688. DOI: 10.14746/se.2015.36.11

Young people engage into their first romantic relationships, which evolve and change in terms of both content and function. The aim of this article is to present the role and importance of adolescents' romantic relationship in their further development and to describe these relations based on a review of research results found in English-language scientific articles. The structure of presentation follows the categories proposed by W.A. Collins: involvement, partner selection, contents, quality, cognitive and emotional processes. Analysis shows that engaging in a romantic relationship during the adolescence period may differentiate the execution of developmental tasks expected during the adolescence period and also the effects of relationships in early adulthood. The research results also show that adolescents' romantic relationships are changeable and dynamic. The picture of these relations differs and depends on whether they were established during early or late adolescence. These properties are reflected in each of the analyzed categories.
\end{abstract}

Key words: adolescents, romantic relationship, developmental tasks

\section{Wprowadzenie}

Zanim adolescenci osiągną 18 lat, więcej niż 80\% z nich doświadczy swoich pierwszych romantycznych relacji. W okresie dzieciństwa bliskie więzi są z reguły ograniczone do członków rodziny i przyjaciół, dopiero w okresie adolescencji pojawia się inny typ bliskości - związki uczuciowe. Zajmują one centralne miejsce w życiu nastolatków, stanowią główny temat rozmów 
i są źródłem silnych emocji. Relacje uczuciowe dominują w tekstach piosenek czy w scenariuszach seriali telewizyjnych skierowanych do nastolatków ${ }^{1}$. Chociaż związki uczuciowe adolescentów są z reguły krótsze niż te nawiązywane przez osoby dorosłe i mają niższy poziom współzależności (np. partnerzy nie mieszkają razem), to mogą potencjalnie mieć znaczenie w dalszym życiu, np. w kwestii zdrowia emocjonalnego, samooceny, poziomu kompetencji społecznych i osiągnięć edukacyjnych. W kontekście romantycznych relacji młodzi ludzie podejmują decyzję o rozpoczęciu współżycia czy stosowaniu antykoncepcji, są też narażeni na akty przemocy, choroby przenoszone drogą płciową, czy przedwczesne rodzicielstwo. W świetle wymienionych konsekwencji romantycznych relacji w okresie dojrzewania $\mathrm{i}$ ich następstw $\mathrm{w}$ życiu dorosłym, podjęcie teoretycznych analiz $\mathrm{w}$ tym obszarze jest uzasadnione. Zwłaszcza że, jak wskazują badacze², przez wiele lat funkcjonowały mity na temat relacji uczuciowych nastolatków, co ograniczyło rozwój badań $\mathrm{w}$ tym obszarze. $\mathrm{W}$ rezultacie, temat randkowania adolescentów częściej pojawia się $\mathrm{w}$ dyskursie publicystycznym, np. przy okazji upublicznienia szokujących informacji czy wydarzeń, niż w dyskursie naukowym. To zagadnienie $\mathrm{w}$ literaturze polskiej jest pobieżnie podejmowane w podręcznikach psychologii rozwojowej, a także w raportach dotyczących sytuacji nastolatków.

\section{Podstawy teoretyczne i metodologiczne}

Jako układ odniesienia dla czynionych analiz przyjęto perspektywę lifespan, charakteryzującą się ujmowaniem zmian rozwojowych w danym etapie życia na tle całości drogi życiowej człowieka ${ }^{3}$. W niniejszym artykule postawiono dwa pytania badawcze. Po pierwsze, jaka jest rola oraz znaczenie relacji uczuciowych adolescentów w ich dalszym rozwoju? Wykorzystując koncepcję rozwoju psychospołecznego E. Eriksona i zadań rozwojowych R.J. Havighursta ${ }^{4}$, omówiono związek pomiędzy zaangażowaniem się w związek uczuciowy w okresie dojrzewania i obszarami rozwoju przewi-

${ }^{1}$ B.B. Brown, C. Feiring, W. Furman, Missing the love boat: why researchers have shied away from adolescent romance, [w:] The Development of Romantic Relationships in Adolescence, red. W. Furman, B.B. Brown, C. Feiring, New York 1999, s. 4-5.

2 W.A. Collins, More than Myth: The Developmental Significance of Romantic Relationships During Adolescence, Journal of Research on Adolescence, 2003, 13(1), s. 1-8; B.B. Brown, C. Feiring, W. Furman, Missing the love boat, s. 1-16.

3 B.M. Newman, Ph.R. Newman, Development Through Life. A Psychosocial Approach, Homewood, Ill. 1984, za: A. Brzezińska, Społeczna psychologia rozwoju, Warszawa 2000, s. 217.

${ }^{4}$ A. Brzezińska, Społeczna psychologia rozwoju, s. 234. 
dzianymi na okres adolescencji oraz tych, które przypadają na okres wczesnej dorosłości $\mathrm{w}$ kontekście stworzenia intymnego, dojrzałego związku. Według B.R. Karney, M.K. Beckett, R.L. Collins i R. Shaw ${ }^{5}$ okres adolescencji jest kluczowy, ponieważ $\mathrm{w}$ tym czasie kształtują się istotne warunki poprzedzające i różnicujące rezultaty romantycznych związków w dorosłości. Autorzy wykorzystali teorie wyjaśniające nawiązywanie relacji uczuciowych przez adolescentów - perspektywa rozwojowa life-span, teoria przywiązania oraz model DEARR (ang. Development of Early Adult Romantic Relationships) dotyczący rozwoju romantycznych relacji w okresie wczesnej dorosłości i stworzyli zintegrowany model. Można go zastosować jako narzędzie do analizy różnych scenariuszy tego, $\mathrm{w}$ jaki sposób doświadczenia adolescentów mogą prowadzić do różnych rezultatów w życiu dorosłym ${ }^{6}$.

Po drugie, dokonano przeglądu badań, aby odpowiedzieć na pytanie: jaki obraz związków uczuciowych adolescentów wyłania się na podstawie wyników dotychczas przeprowadzonych badań? W tym celu przeszukano bazę danych EBSCO i ScienceDirect w oparciu o następujące słowa kluczowe: adolescents, teenagers, romantic relationship, love. Wyniki wyszukiwania ze względu na ich liczbę (EBSCO - 853 artykuły, ScienceDirect - 921 artykuły) musiały zostać ograniczone. Zastosowano następujące kryteria selekcji: język (pozostawiono tylko teksty anglojęzyczne), obszar geograficzny (artykuły dotyczyły badań przeprowadzonych w Europie i Stanach Zjednoczonych), tematyka (pominięto teksty, które w całości dotyczyły np. inicjacji seksualnej, przemocy w związkach uczuciowych adolescentów, czy wczesnego rodzicielstwa itp.), typ relacji (prezentowane wyniki badań dotyczą tylko związków heteroseksualnych). Ostatecznie włączono do opracowania 27 artykułów. Struktura prezentowania wyników badań dotyczących związków uczuciowych została wyznaczona za pomocą 5 kategorii zaproponowanych przez W.A. Collinsa7.

W literaturze anglojęzycznej najczęściej pojawia się określenie romantic relationships, które może być tłumaczone jako relacja uczuciowa lub romantyczna. Przyjęto określenie 'związek uczuciowy', jako kategoria pojęciowa węższa względem ogólnie rozumianego pojęcia 'relacja uczuciowa', ponieważ relacje uczuciowe koncentrują się na wzajemnych stosunkach ich uczestników, a ich wyrazem może być zaangażowanie w związek uczuciowy. Anglojęzyczna definicja romantycznych relacji pozostaje spójna z zakresem znaczeniowym tego, co nazywamy związkiem uczuciowym. Przyjęto

${ }^{5}$ B.R. Karney i in., Adolescent Romantic Relationships as Precursors of Healthy Adult Marriages. A Review of Theory, Research, and Programs, RAND Corporation 2007, s. 4, 72.

${ }^{6}$ Tamże, s. 38-45.

7 W.A. Collins, More than Myth, s. 8. 
więc, że związek uczuciowy to trwające, dobrowolne i wzajemne interakcje, które muszą zostać ustalone przez obydwie, a nie tylko jedną osobę z pary. Taką relację charakteryzuje intensywność, szczególnie jeśli chodzi o ekspresję uczuć, może też wiązać się z oczekiwaniem podjęcia kontaktów seksualnych - teraz albo w przyszłości ${ }^{8}$. Inni autorzy przyjmują, że uczuciowa/romantyczna jest też relacja, w której pojawiają się uczucia erotyczne, ale partnerzy nie podejmują zachowań seksualnych?

\section{Rola romantycznych relacji w rozwoju adolescentów}

Randkowanie i nabywanie pierwszych doświadczeń w byciu w związku ważne jest samo w sobie, szczególnie dla młodych ludzi, ale pełni też rolę w kształtowaniu ogólnego przebiegu rozwoju w okresie dorastania. Stanowi jedno z zadań rozwojowych, ale może też wiązać się z realizacją pozostałych zadań przewidzianych na okres dojrzewania, jak: rozwój tożsamości, przekształcenie się więzów rodzinnych, rozwój bliskich relacji z rówieśnikami, rozwój seksualności, osiągnięcia szkolne i planowanie kariery ${ }^{10}$ oraz przypadających na okres wczesnej dorosłości. Osoby, które nie będą miały doświadczeń w randkowaniu mogą nie być wystarczająco przygotowane do nawiązania intymnej relacji w późniejszym wieku'11.

Analizując dostępne modele procesów tożsamościowych dotyczące eksploracji wszerz oraz narzędzia służące do badania jej wymiarów, Maria Kłym i Jan Cieciuch wyróżnili 12 takich obszarów, które mogą się pojawić w okresie wczesnej adolescencji i poddali je badaniu. W weryfikowanym modelu uwzględniono relacje chłopak-dziewczyna i potwierdzono ich istotność $\mathrm{w}$ kształtowaniu się tożsamości ${ }^{12}$. Romantyczne relacje mogą pełnić rolę $\mathrm{w}$ rozwoju poczucia tożsamości na dwa sposoby. Po pierwsze, adolescenci rozwijają koncepcje siebie w różnych sferach, $\mathrm{np}$. w kontakcie $\mathrm{z}$ grupą rówieśników, znajomych i przyjaciół, ale też w interakcji z partnerem. Romantyczna koncepcja siebie jest związana z tym, czy ktoś jest $\mathrm{w}$ relacji uczu-

8 Tamże, s. 2.

${ }_{9}^{9}$ B.R. Karney i in., Adolescent Romantic Relationships, s. 8.

$10 \mathrm{~W}$. Furman, L. Shaffer, The role of romantic relationships in adolescent development, [w:] Adolescent romantic relations and sexual behavior: Theory, research, and practical implications, red. P. Florsheim, Mahwah, NJ 2003, s. 3.

11 E.H. Erikson, Growth and crisis of the healthy personality, [w:] Psychological Issues, vol. 1 Identity and the Life Cycle, red. E.H. Erikson, New York 1959, za: M.J. Zimmer-Gembeck, J. Siebenbrunder, W.A. Collins, Diverse aspects of dating: associations with psychosocial functioning from early to middle adolescence, Journal of Adolescence, 2001, 24, s. 314.

12 M. Kłym, J. Cieciuch, The Early Identity Exploration Scale - a measure of initial exploration in breadth during early adolescence, Frontiers of Psychology, 2015, 6, s. 5-7. 
ciowej i jaka ona jest. Nastolatek, który ma pozytywne doświadczenia może myśleć o sobie jako o atrakcyjnym partnerze, podczas gdy osoba, która doświadczyła trudności może czuć się niepewna, nie wie czy potrafi nawiązać satysfakcjonującą relację ${ }^{13}$. Po drugie, zdobyte doświadczenia i romantyczna koncepcja siebie mogą także różnicować poczucie własnej wartości oraz inne aspekty „ja”, np. związane z oceną własnej atrakcyjności fizycznej i akceptacji rówieśników ${ }^{14}$. Wykazano, że u osób dorosłych samoocena, poziom pewności siebie i fizycznej atrakcyjności różnicują czas rozpoczęcia, częstotliwość i jakość relacji, podobnie może też być u osób młodszych ${ }^{15}$.

Rozpoczęcie randkowania może wiązać się z negatywnymi konsekwencjami dla rozwoju adolescentów i ich funkcjonowania psychospołecznego, zwłaszcza kiedy nastąpiło ono wcześnie i było intensywne. Jest prawdopodobne, że młodzi ludzie, którzy umawiali się na spotkania mając mniej niż 14 lat lub często randkowali będą spożywać substancje psychoaktywne i wezmą udział w zachowaniach przestępczych. M.J. Zimmer-Gembeck, J. Siebenbrunder, W.A. Collins ${ }^{16}$ przywołują publikacje wydane w latach 90. ubiegłego wieku, jak również prezentują wyniki badań własnych, że silne zaangażowanie się $\mathrm{w}$ randki $\mathrm{w}$ wieku 16 lat wiąże się ze słabszym funkcjonowaniem psychospołecznym (dotyczy to np. zdrowia psychicznego i motywacji szkolnej) oraz wystąpieniem problemów w zachowaniu we wczesnym i środkowym okresie dojrzewania. Częste randkowanie może spowodować nasilenie problemów z okresu wczesnego dorastania, ale kierunek wpływu może być też odwrotny - spotęgowanie problemów może prowadzić do częstszego umawiania się. Status socjoekonomiczny może także różnicować czas rozpoczęcia umawiania się na randki - im niższy, tym szybciej nawiązywane są romantyczne relacje. Dla niektórych młodych osób doświadczenie odrzucenia lub konfliktów w związku może nie sprzyjać zachowaniu zdrowia psychicznego, np. zerwanie z partnerem może łączyć się z pierwszym epizodem depresji. Także u respondentów, którzy mówili o braku bliskości czy wymieniali inne negatywne właściwości relacji z partnerem zanotowano wysoki poziom symptomów depresyjnych; podobną tendencję zauważono u osób angażujących się w przypadkowy seks ${ }^{17}$.

Młodzież jest też szczególnie narażona na zaangażowanie się $\mathrm{w}$ relacje, w których może pojawić się przemoc. W zależności od badań, na które po-

${ }^{13} \mathrm{~W}$. Furman, L. Shaffer, The role of romantic relationships, s. 4-5.

14 S. Harter, Manual for the self-perception profile for adolescents, Denver, CO 1988, za: W. Furman, L. Shaffer, The role of romantic relationships, s. 5.

15 W.A. Collins, More than Myth, s. 16.

16 M.J. Zimmer-Gembeck, J. Siebenbrunder, W.A. Collins, Diverse aspects of dating, s. 319, 327-332; B.R. Karney i in., Adolescent Romantic Relationships, s. 65.

17 B.R. Karney i in., Adolescent Romantic Relationships, s. 64. 
wołują się autorzy opracowań, procent nastolatków, które doświadczyły przemocy jest różny. Autorzy drugiej części badań Add Health (National Longitudinal Study of Adolescent Health przeprowadzono w latach 1994-1995, następnie rok i siedem lat później) podają, że 21\% nastoletnich chłopców i 22\% nastoletnich dziewcząt doświadczyło w ostatnich 18 miesiącach przemocy ze strony swojego partnera. Najczęściej przytaczane formy agresji to: przeklinanie lub obrażanie w obecności innych osób, popychanie, grożenie i rzucanie czymś w kierunku partnera ${ }^{18}$. Co więcej, zdarza się, że nastoletnie dziewczęta są namawiane albo zmuszane do podejmowania zachowań, na które nie wyrażają zgody.

Randkowanie może być jednym z najsilniejszych czynników przyczyniających się do intensyfikacji konwencjonalnych ról związanych z płcią - adolescenci zachowują się w sposób, o którym myślą, że jest atrakcyjny dla osób przeciwnej płci ${ }^{19}$. Z drugiej strony, rozwój związku uczuciowego może utrudniać proces rozwoju tożsamości, np. konsekwencją zaangażowania $\mathrm{w}$ relację może być wczesne rodzicielstwo ${ }^{20}$.

Okres adolescencji to czas, kiedy relacje rodzice-dzieci ulegają renegocjacji i transformacji; mogą temu towarzyszyć konflikty i napięcia z powodu odmiennych oczekiwań jednej i drugiej strony. Romantyczne relacje na kilka sposobów pełnią rolę $\mathrm{w}$ tych przemianach. Po pierwsze, dzieci spędzają z rodzicami mniej czasu na rzecz przyjaciół i partnera, także do nich zwracają się z prośbą o wsparcie (w późnej fazie adolescencji to partner staje się figurą przywiązania). Po drugie, relacje adolescentów są często źródłem konfliktów, ponieważ rodzice dostrzegają niebezpieczeństwa związane $z$ umawianiem się na randki, a nastolatkowie sami chcą kontrolować swoje osobiste sprawy. Może być jednak tak, że to nie romantyczne relacje wywołują zmiany w stosunkach rodzinnych, ale sytuacja $\mathrm{w}$ domu i chęć zapomnienia o problemach prowadzi do poszukiwania partnera. Nawet jeśli randkowanie nie jest głównym źródłem konfliktów, to rodzice mogą doświadczać ambiwalentnych uczuć myśląc o relacjach uczuciowych swoich dzieci21.

Istotna wydaje się też struktura rodziny oraz stosunki w niej panujące. P. Summers i inni ${ }^{22}$ porównali style przywiązania młodych dorosłych, których rodzice rozwiedli się albo pozostawali małżeństwem $\mathrm{w}$ czasie, kiedy

18 Tamże, s. 25.

19 C. Feiring, Gender identity and the development of romantic relationships in adolescence, [w:] The development of romantic relationships in adolescence, red. W. Furman, B.B. Brown, C. Feiring, Cambridge, UK 2000, za: W. Furman, L. Shaffer, The role of romantic relationships, s. 5.

${ }^{20}$ W. Furman, L. Shaffer, The role of romantic relationships, s. 5.

21 Tamże, s. 6-8.

22 P. Summers i in., Parental divorce during early adolescence in Caucasian families: The role of family process variables in predicting the long-term consequences for early adult psychosocial adjustment, Journal of Consulting and Clinical Psychology, 1998, 66. 
ich dzieci były w okresie dorastania. Zauważyli, że dzieci rozwiedzionych rodziców mają mniej bezpieczny styl przywiązania. Wykazują mniej optymizmu wobec perspektyw przyszłego życia małżeńskiego i mają wobec niego bardziej negatywne postawy. Innymi słowy, rozwód rodziców może różnicować rezultaty przyszłych związków dzieci poprzez bezpośredni wpływ na ich poglądy i postawy co do romantycznych relacji. Znacząca część opracowań dotyczy jednak prób wyjaśnienia rozwoju związków uczuciowych w okresie adolescencji i dorosłości na podstawie relacji pomiędzy członkami rodziny. Przeprowadzono liczne badania podłużne (m.in. The Minnesota Longitudinal Study of Parents and Children), w których monitorowano pierwsze interakcje matki z niemowlęciem, późniejsze doświadczenia tych dzieci, także w kontekście romantycznych związków. Im bardziej pozytywne są interakcje dziecka z matką, tym bardziej bezpieczne występują reprezentacje relacji z rówieśnikami oraz romantycznym partnerem $\mathrm{w}$ życiu nastoletnim i dorosłym. Przez długi czas koncentrowano się głównie na roli matki, ale później uznano, że także ojciec jest znaczącą postacią w rozwoju dziecka, szczególnie stymulując je do podejmowania aktywności i zachęcając do eksploracji23. Co ważne, także późniejsze relacje dorastających dzieci i rodziców mogą być predyktorem rezultatów dalszych romantycznych doświadczeń24.

We wczesnym okresie dojrzewania adolescenci najsilniej odczuwają potrzebę bycia członkiem popularnej "paczki”, jednak jej siła zmniejsza się z wiekiem, ponieważ młodzi ludzie przynależą do wielu grup i łatwiej im przenikać pomiędzy ich strukturami ${ }^{25}$. Wraz ze wzrostem ilości czasu, który młodzi ludzie spędzają z rówieśnikami, wzrasta też liczba interakcji z osobami płci przeciwnej. Młodzi ludzie mogą w tym czasie rozwijać umiejętności współdziałania, ale także zrewidować nawiązane znajomości, zbudować je od nowa i zaangażować się uczuciowo w romantyczną relację. Poznawcze reprezentacje związku i przyjaźni są ze sobą połączone. Adolescent, który ceni intymność oraz bliskość i oczekuje od partnera, aby był dostępny i czuły, ma też podobne oczekiwania wobec swojego przyjaciela ${ }^{26}$. Relacje z przyjaciółmi i rodzicami są nie tylko związane z jakością nastoletnich romantycznych relacji, ale także na nie wpływają. M. Scharf i O. Mayseless ${ }^{27}$ zauważyli, że na ich podstawie można przewidzieć nawiązanie intymnego

${ }^{23}$ E-M. Merz, S. Jak, The long reach of childhood experiences influence close relationships and loneliness across life, Advances in Life Course Research, 2013, 18, s. 213.

24 B.R. Karney i in., Adolescent Romantic Relationships, s. 53-56.

${ }^{25}$ L. Gavin, W. Furman, Age difference in adolescents' perceptions of their peer groups. Developmental Psychology, 1989, 25, za: W. Furman, L. Shaffer, The role of romantic relationships, s. 8.

26 W. Furman, L. Shaffer, The role of romantic relationships, s. 8-10.

${ }^{27} \mathrm{M}$. Scharf, O. Mayseless, The capacity for romantic intimacy: exploring the contribution of best friend and marital and parental relationships, Journal of Adolescence, 2001, 24. 
związku 4 lata później (w badaniu podłużnym badano jakość nastoletnich relacji w wieku 17 lat i później, kiedy respondenci mieli 21 lat) ${ }^{28}$.

Randkujący nastolatek nie tylko może powiększyć grono swoich znajomych, które z czasem trwania związku coraz bardziej pokrywa się z siecią społeczną partnera, ale także podnieść swoją pozycję w grupie, szczególnie kiedy spotyka się z osobą atrakcyjną i popularną. Co więcej, osoby otrzymujące wiele pozytywnych nominacji w testach socjometrycznych również częściej chodzą na randki ${ }^{29}$. Nadal jednak funkcjonują podwójne standardy dotyczące podejmowania zachowań seksualnych przez młodzież - w przypadku nawiązania kontaktów seksualnych przez chłopców ich pozycja wzrasta, natomiast $\mathrm{w}$ przypadku dziewcząt ich status $\mathrm{w}$ grupie może być zagrożony ${ }^{30}$. Nawiązanie poważnej relacji uczuciowej może być tematem żartów, jeśli członkowie grupy rówieśniczej postrzegają przedstawicieli płci przeciwnej tylko jako obiekt seksualnych podbojów ${ }^{31}$.

W okresie dojrzewania nastolatek staje się fizycznie dojrzały do reprodukcji i pojawiają się u niego pragnienia seksualne, także $w$ tym czasie najczęściej dochodzi do inicjacji seksualnej. Należy zauważyć, że w ostatnim stuleciu zwraca się uwagę na wyraźne przyspieszenie rozwoju fizycznego adolescentów pod różnymi jego względami, przy jednocześnie mniej intensywnym przyspieszeniu dojrzewania psychicznego. Wyraźnie pogłębia się różnica między osiągnięciem podobieństwa fizycznego do osób dorosłych, zdolnością do prokreacji i możliwościami poznawczymi a dojrzałością emocjonalną i społeczną. Akceleracja rozwoju wyraża się między innymi w obniżeniu wieku osiągania dojrzałości płciowej i tym samym także wcześniejszym rozpoczęciem współżycia seksualnego (jednak ta współzależność jest silniejsza u chłopców ${ }^{32}$. W ramach przygodnych lub poważnych związków dochodzi do podejmowania i uczenia się zachowań seksualnych. Mają one również miejsce w krótkich relacjach typu "hook-up” (kontakt seksualny $\mathrm{z}$ osobą, z którą nie jest się w związku) lub pomiędzy przyjaciółmi, którzy nie są romantycznie związani, ale angażują się w łagodne formy aktywności

28 S. Shulman, I. Seiffge-Krenke, Adolescent romance: between experience and relationships, Journal of Adolescence, 2001, 24, s. 423-424; B.R. Karney i in., Adolescent Romantic Relationships, s. 60 .

${ }^{29}$ W. Furman, L. Shaffer, The role of romantic relationships, s. 9.

30 S.L. Eyre, V. Hoffman, S.G. Millstein, The gamesmanship of sex: A model based on African American adolescent accounts, Medical Anthropology Quarterly, 1998, 12, za: W. Furman, L. Shaffer, The role of romantic relationships, s. 10.

31 E. Anderson, Streetwise: Race, class, and change in an urban community, Chicago 1990, za: W. Furman, L. Shaffer, The role of romantic relationships, s. 10.

32 Z. Izdebski, Seksualność Polaków na początku XXI wieku. Studium badawcze, Kraków 2012, za: A. Oleszkowicz, A. Senejko, Psychologia dorastania. Zmiany rozwojowe w dobie globalizacji, Warszawa 2013, s. 28-29, 34. 
seksualnej33. Nawiązanie kontaktu o charakterze seksualnym jest ściśle związane z tym, jak młodzież ogólnie określa swoje relacje (np. stały związek czy randkowanie) niż z deklaracją o częstotliwości przejawiania określonych zachowań, takich jak pójście na randkę. Posiadanie stałego partnera, a nie samo randkowanie wyjaśnia zdobycie pierwszych doświadczeń seksualnych $^{34}$. Chociaż zachowania seksualne są powszechne $w$ wielu typach relacji, to najczęściej występują w związkach opisywanych jako bliskie i pełne zaangażowania. Według dwóch trzecich osób w wieku 12-19 lat seks powinien wystąpić tylko $\mathrm{w}$ takim związku. Miłość i bycie w związku jest najczęściej zgłaszanym powodem, dla którego młodzież rozpoczyna swoje życie seksualne ${ }^{35}$. I faktycznie, w innych badaniach $62 \%$ chłopców w wieku 15-19 lat, którzy mieli stosunek seksualny $\mathrm{w}$ przeciągu ostatnich trzech miesięcy określiło nawiązaną relację jako stałą, w przypadku kobiet było to $75 \%$. Zdarzało się, że respondenci (14\%) wskazywali swojego przyjaciela jako pierwszego partnera seksualnego. Wykazano, że im młodszy wiek inicjacji seksualnej dziewcząt, tym jest bardziej prawdopodobne, że opiszą one partnera jako kogoś, kogo spotkały lub kto był ich przyjacielem - 33\% dziewcząt w wieku 14 lat lub młodszych w porównaniu z 11\% nastolatek mających 1719 lat $^{36}$. Pierwsze doświadczenia seksualne nabywane są częściej z osobą bardziej doświadczoną i starszą. Należy jednak zauważyć, że młodzi ludzie raczej selektywnie podchodzą do tego, z kim wchodzą w kontakt i liczba ich partnerów seksualnych waha się między jednym a dwoma ${ }^{37}$, przy czym płeć różnicuje tę liczbę - dziewczęta częściej miały jednego partnera w okresie ostatnich 12 miesięcy (61\% aktywnych seksualnie dziewcząt oraz 47\% chłopców), a chłopcy dwóch (32\% chłopców i 22\% dziewcząt) albo wcale (14\% chłopców i 9\% dziewcząt) ${ }^{38}$. Przynależność religijna i uczestnictwo w praktykach religijnych mogą być tymi zmiennymi (odpowiedniki bardziej konserwatywnych postaw wobec seksualności), za pomocą których można wyjaśnić moment nawiązywania pierwszych kontaktów seksualnych wśród adolescentów, tj. odłożenie ich w czasie ${ }^{39}$.

33 B.R. Karney i in., Adolescent Romantic Relationships, s. 20.

${ }^{34}$ E.C. Cooksey, F.L. Mott, S.A. Neubauer, Friendships and early relationships: Links to sexual initiation among American adolescents born to young mothers, Perspectives on Sexual and Reproductive Health, 2002, 34 za: B.R. Karney i in., Adolescent Romantic Relationships, s. 22, 65.

35 B. Albert, With One Voice 2004: America's Adults and Teens Sound Out About Teen Pregnancy. An Annual Survey, Washington D.C. 2004, za: B.R. Karney i in., Adolescent Romantic Relationships, s. 15.

${ }^{36}$ B.R. Karney i in., Adolescent Romantic Relationships, s. 22.

37 W. Furman, L. Shaffer, The role of romantic relationships, s. 10-12.

38 B.R. Karney i in., Adolescent Romantic Relationships, s. 23.

39 Tamże, s. 63. 
Przyjaciele i grupa rówieśnicza mogą mieć zarówno pozytywny, jak i negatywny wpływ na uczestnictwo i osiągnięcia szkolne adolescentów. $Z$ jednej strony, wspierający znajomi mają tendencję do przejawiania większego zainteresowania szkoła, ale $\mathrm{z}$ drugiej strony trwanie $\mathrm{w}$ trudnej relacji może być dla nastolatka destrukcyjne. Występuje korelacja pomiędzy wczesnym zaangażowaniem się $\mathrm{w}$ romantyczne relacje i słabszymi osiągnięciami edukacyjnymi. Podobnie jest $\mathrm{w}$ przypadku randkowania oraz podejmowania zachowań seksualnych i uzyskiwanych wyników w szkole. Być może powodem złych ocen jest niedostateczny czas poświęcony na naukę, ponieważ jest on wykorzystywany na spotkania z partnerem. Nie można jednoznacznie stwierdzić, jaki związek występuje i o jakim wpływie możemy mówić, ponieważ silnie zależy on od natury nawiązanej relacji i samej osoby partnera ${ }^{40}$. Zauważono jednak, że późne nawiązanie uczuciowej relacji wiąże się z wyższą inteligencją. Osoby, które nie randkują w okresie dorastania mają wyższe oceny ${ }^{41}$.

Romantyczni partnerzy mogą także stać się towarzyszami, z którymi adolescenci mogą dzielić się swoimi planami i marzeniami, także dotyczącymi wyboru szkoły, planowania kariery, czy założenia rodziny. Zdarza się jednak, że realizację tych decyzji ogranicza pojawienie się dziecka ${ }^{42}$.

\section{Konsekwencje romantycznych relacji adolescentów w życiu dorosłym}

Na podstawie 20-letnich badań podłużnych ustalono, że rezultaty romantycznej relacji dorosłego człowieka mają związek z bardzo wczesnymi doświadczeniami $\mathrm{w}$ okresie niemowlęctwa, ale istotne jest również to, co wydarzyło się $\mathrm{w}$ innych typach relacji $\mathrm{w}$ trakcie kolejnych etapów rozwoju społecznego, włączając $\mathrm{w}$ to także romantyczne relacje $\mathrm{w}$ okresie adolescencji i wczesnej dorosłości. W badaniu wzięły udział matki i ich nowo narodzone dzieci, które były badane w regularnych odstępach czasu na każdym etapie rozwojowym. Badaczy interesował m.in.: styl przywiązania dziecka do opiekunów, rozwój kompetencji społecznych w okresie średniego dzieciństwa, relacja z najlepszym przyjacielem, rozwiązywanie konfliktów, regulacja emocjonalna $\mathrm{w}$ trudnych sytuacjach $\mathrm{z}$ partnerem, trwanie związku

${ }^{40}$ W. Furman, L. Shaffer, The role of romantic relationships, s. 12-13.

${ }^{41}$ B.R. Karney i in., Adolescent Romantic Relationships.

42 R.L. Coley, P.R. Chase-Lansdale, Adolescent pregnancy and parenthood: Recent evidence and future directions, American Psychologist, 1998, 53, za: W. Furman, L. Shaffer, The role of romantic relationships, s. 13. 
i jakość relacji uczuciowej w okresie wczesnej dorosłości. Wzory myśli, uczuć i działań związane $\mathrm{z}$ dotychczasowymi relacjami - ich poznawcze reprezentacje są tym, co łączy wczesne doświadczenia z opiekunami i te późniejsze z rówieśnikami, bliskimi przyjaciółmi i ostatecznie z romantycznym partnerem. Pozytywne wczesne doświadczenia mogą pełnić funkcję ochronną, np. w przypadku nawiązania słabej jakościowo relacji uczuciowej i odwrotnie - satysfakcjonujące relacje w życiu dorosłym mogą pełnić funkcję kompensacyjną wczesnodziecięcych relacji z opiekunami ${ }^{43}$. Według B.R. Karney, M.K. Beckett, R.L. Collins, R. Shaw ${ }^{44}$ okres adolescencji jest kluczowy, ponieważ w tym czasie kształtują się istotne warunki poprzedzające i różnicujące rezultaty romantycznych związków w dorosłości. Już na tym etapie można wzmocnić fundamenty przyszłego zdrowego i dojrzałego związku oraz zapobiegać przenoszeniu negatywnych wzorów.

\section{Przegląd wyników badań dotyczących relacji uczuciowych adolescentów}

Dokonany przegląd badań miał służyć poszukiwaniu odpowiedzi na następujące pytanie: Jaki obraz związków uczuciowych adolescentów wyłania się na podstawie wyników dotychczas przeprowadzonych badań? Struktura prezentowania wyników badań dotyczących związków uczuciowych została wyznaczona za pomocą 5 kategorii zaproponowanych przez W.A. Collinsa45: uczestnictwo (ang. involvement), wybór partnera (partner selection), zawartość lub treść (content), jakość (quality) oraz procesy poznawcze i emocjonalne (cognitive and emotional processes).

Najczęściej wykorzystywanym wskaźnikiem występowania romantycznych relacji wśród osób $\mathrm{w}$ okresie dorastania jest ich uczestnictwo $\mathrm{w}$ randkowaniu. Odnosi się do tego, czy młodzi ludzie randkują, w jakim wieku nabywają swoje pierwsze doświadczenia z tym związane, jaka jest częstotliwość i okres trwania relacji, a także ich konsekwencje. Opisywanie romantycznych relacji wyłącznie $\mathrm{w}$ tym wymiarze ogranicza ich zrozumienie, jeśli celem jest wyjaśnienie ich znaczenia w aspekcie rozwojowym.

Sprawozdawczość na temat czasu, kiedy młodzież rozpoczyna związek jest trudne, ponieważ nie zawsze owa młodzież dokładnie wie, kiedy relacja

43 J.A. Simpson $\mathrm{i}$ in., The impact of early interpersonal experience on adult romantic relationship functioning, [w:] Mechanisms of social connection: From brain to group, red. M. Mikulincer, P. Shaver, Washington 2014, s. 221-231.

${ }^{44}$ B.R. Karney i in., Adolescent Romantic Relationships, s. 4, 72.

${ }^{45}$ W.A. Collins, More than Myth, 2003, 13(1), s. 8. 
uczuciowa została nawiązana, szczególnie jeśli partnerzy byli wcześniej przyjaciółmi ${ }^{46}$. W wyjaśnieniu tego faktu może być pomocne przywołanie modelu rozwoju uczuciowych relacji adolescentów. Przed okresem dorastania, chłopcy i dziewczęta budują relacje przede wszystkim z rówieśnikami tej samej płci47, a w kolejnych latach zaczynają myśleć o osobach przeciwnej płci i dochodzi do częstszych interakcji z nimi ${ }^{48}$. Z grup mieszanych wyłaniają się pary, które są związane jakąś wspólną działalnością, aż wreszcie oddzielają się i spotykają tylko we dwójkę ${ }^{49}$. Doświadczenia adolescentów mają szeroki zakres - począwszy od wyobrażeń do interpersonalnych interakcji trwających krótszy bądź dłuższy okres ${ }^{50}$. Romantyczna relacja pomiędzy nastolatkami może przyjmować różnorodną formę: od tej zbliżonej do relacji pomiędzy przyjaciółmi, przez swobodne randkowanie, aż po wyłączność i lojalność partnerów ${ }^{51}$. Czasami zdarza się, że adolescenci mają trudność ze zdefiniowaniem relacji, w jakiej pozostają - czy nadal jest to przyjaźń, czy już związek uczuciowy ${ }^{52}$ albo ich nie rozróżniają. Szczególnie dotyczy to osób we wczesnym okresie dojrzewania, kiedy tym kontaktom brakuje społecznej i psychologicznej głębi53. Wraz z wiekiem zwiększa się przejrzystość na temat bycia czyjąś dziewczyną lub czyimś chłopakiem. Uczniowie w wieku 11-12 lat potrafią wyjaśnić, co liczy się jako randka albo bycie razem, a już dwa lata później natychmiast rozumieją pytania o relacje uczuciowe ${ }^{54}$. Adolescenci używają też wielu pojęć na określenie nawiązywanych relacji; dotyczy to szczególnie tych, które są traktowane jako mniej

${ }^{46}$ K.P. Carver, K. Joyner, J.R. Udry, National estimates of adolescent romantic relationships, [w:] Adolescent Romantic Relations and Sexual Behavior: Theory, Research, and Practical Implications, red. P. Florsheim, Mahwah NJ 2003, za: W.A. Collins, More than Myth, s. 4.

47 W. Furman, The Emerging Field of Adolescent Romantic Relationships, Current directions in Psychological Science, 2002, 11, s. 178.

${ }^{48}$ M.H. Richards i in., Developmental patterns and gender differences in the experience of peer companionship during adolescence, Child Development, 1998, 69, za: W. Furman, The Emerging Field, s. 178.

49 J. Connolly i in., Mixed-Gender Groups, Dating, and Romantic Relationships in Early Adolescence. Journal of Research on Adolescence, 2004, 14(2).

50 B.B. Brown, C. Feiring, W. Furman, Missing the love boat, za: S. Shulman, I. SeifgeKrenke, Adolescent romance: between experience and relationships. Journal of Adolescence, 2001, 24, s. 417.

51 J.C. LaVoie i in., Boundary Determinants in Adolescent Same-sex and Cross-sex Relationships, San Diego, CA 1998, za: S. Shulman, I. Seifge-Krenke, Adolescent romance, s. 417.

52 C. Leaper, K.J. Anderson, Gender development and heterosexual romantic relationships during adolescence, [w:] Romantic Relationships in Adolescence: Developmental Perspectives, red. S. Shulman, W.A. Collins, San Francisco, CA 1997, za: S. Shulman, I. Seiffge-Krenke, Adolescent romance, s. 417.

53 B.B. Brown, C. Feiring, W. Furman, Missing the love boat, za: S. Shulman, O. Kipnis, Adolescent romantic relationships: a look from the future, Journal of Adolescence, 2001, 24, s. 337.

${ }^{54}$ B.R. Karney i in., Adolescent Romantic Relationships, s. 14. 
poważne. W przypadku związków bardziej intymnych więcej niuansów dostrzega starsza młodzież, aniżeli osoby młodsze, dla których ta kategoria jest dosyć jednorodna 55 .

Bez wiarygodnych raportów, kiedy rozpoczął się związek, oszacowanie czasu trwania relacji może być trudne. Młodzież jest natomiast świadoma, kiedy nastąpił rozpad ich związku, gdyż wiązało się to zwykle z konkretnym wydarzeniem ${ }^{56}$. Duża część adolescentów deklaruje, że była w związku, który trwał 11 lub więcej miesięcy i ten odsetek rośnie wraz z wiekiem respondentów (od 20\% wśród 14-latków i osób młodszych, do 35\% u 15-16latków i prawie $60 \% \mathrm{w}$ grupie 17 i 18-latków) ${ }^{57}$. Obliczono medianę trwania romantycznych związków - 16 miesięcy dla dziewcząt i 12 miesięcy dla chłopców. Starsza młodzież deklarowała, że ich związki były dłuższe. I tak, średni czas trwania dla młodzieży w wieku 14 lat wynosi 5 miesięcy, dla młodzieży w wieku między 15 i 16 było to 8 miesięcy, a 21 miesięcy dla osób w wieku powyżej 16 roku życia ${ }^{58}$. Na podstawie wyników badań podłużnych przeprowadzonych na dużej próbie osób w wieku 12-18 lat (Add Health Wave I) ${ }^{59}$ zauważono, że niezależnie od czasu trwania relacji znacząca większość nastolatków doświadczyła bycia w związku albo podejmowała zachowania, które by o tym świadczyły (np. trzymanie się za rękę, całowanie, mówienie komuś, że się go kocha itp.) w ciągu ostatnich 18 miesięcy - odpowiednio $55 \%$ i $35 \%$. Brakuje reprezentatywnych danych, na które można byłoby się powołać w celu przybliżenia procentu polskich nastolatków, którzy mają partnera. Wśród warszawskiej młodzieży licealnej jest to około $40 \%$ (37\% chłopców ma dziewczynę i $44 \%$ dziewcząt ma chłopaka - w badaniach wzięła udział 350-osobowa grupa ${ }^{60}$. Niemniej jednak w raportach, które dotyczą młodzieży, wskazuje się, że miłość jest jedną z najwyżej cenionych wartości61, a spotkania z kolegami, przyjaciółmi, dziewczyną/chłopakiem są

55 L. Guzman i in., Telling It Like It Is: Teen Perspectives on Romantic Relationships, Childs Trends, 2009, 44, s. 2.

${ }^{56}$ B.R. Karney i in., Adolescent Romantic Relationships, s. 20.

57 W.A. Collins, More than Myth, s. 4.

58 B.R. Karney i in., Adolescent Romantic Relationships, s. 20-21.

${ }^{59}$ K.P. Carver, K. Joyner, J.R. Udry, National estimates of adolescent romantic relationships, [w:] W: Adolescent Romantic Relations and Sexual Behavior: Theory, Research, and Practical Implications, red. P. Florsheim, Mahwah NJ 2003, za: B.R. Karney i in., Adolescent Romantic Relationships, s. 21.

${ }^{60} \mathrm{H}$. Tomaszewska, Młodzież, rówieśnicy i nowe media: społeczne funkcje technologii komunikacyjnych w życiu nastolatków, Warszawa 2012, s. 192.

${ }^{61} \mathrm{R}$. Boguszewski, K. Kowalczuk, Aspiracje, dążenia i plany życiowe młodziė̇y, [w:] Młodzież 2013, 2014, s. 6, http://www.cinn.gov.pl/portal?id=15\&res_id=673746, [dostęp: 06.11.2014]. 
najczęstszą formą spędzania wolnego czasu - wskazaną przez $88 \%$ badanych według autorów raportu Młodzież $2013^{62}$.

Istnieje bogata literatura na temat atrakcyjności interpersonalnej i procesów selekcji partnerów w kontekście osób dorosłych, natomiast mało wiadomo o preferencjach i wyborach adolescentów. Badania wykazały, że młodzież wybiera raczej partnerów podobnych do siebie $\mathrm{w}$ odniesieniu do: statusu społeczno-ekonomicznego, średniej ocen, planów wyboru uczelni, przywiązania do szkoły, kłopotów w szkole, zachowań związanych z piciem alkoholu czy poziomem inteligencji. Ta sama młodzież ma również tendencję do wyboru partnerów o podobnych doświadczeniach seksualnych, którzy byli również zawieszeni w szkole, mają podobny stosunek do palenia ${ }^{63}$. Reguła podobieństwa może być tutaj związana z potrzebą akceptacji oraz towarzystwa, które silnie uwidaczniają się w okresie wczesnej adolescencji. M.J. Zimmer-Gembeck, J. Siebenbruner i W.A. Collins ${ }^{64}$ zauważają, że wczesne rozpoczęcie randkowania i większe spożycie alkoholu można prognozować na podstawie dużej towarzyskości, mniejszej impulsywności w dzieciństwie, wyższej jakości przyjaźni, większej akceptacji rówieśników oraz bardziej dojrzałego wyglądu i fizycznej atrakcyjności w wieku 13 lat, co w ostateczności prowadzi do większej liczby partnerów seksualnych w wieku 19 lat ${ }^{65}$. Oczekiwanie aprobaty lub dezaprobaty może być także czynnikiem prognostycznym wczesnej inicjacji seksualnej66, podobnie jak posiadanie grona znajomych, którzy są już aktywni seksualnie ${ }^{67}$.

Jeśli chodzi o wiek, to dorastający chłopcy mają tendencję do wyboru starszych partnerek, a w okresie późnego dorastania spotykają się z kole-

62 R. Boguszewski i in., Młodzież o sobie: wartości, obyczajowość, grupy odniesienia, [w:] Młodzież 2013, 2014, s. 130, http://www.cinn.gov.pl/portal?id=15\&res_id=673746, [dostęp: 06.11.2014].

${ }^{63}$ P.S. Bearman, J. Moody, K. Stovel, Chains of affection: The structure of adolescent romantic and sexual networks, American Journal of Sociology, 2004, 110, za: B.R. Karney i in., Adolescent Romantic Relationships, s. 24, 60.

${ }_{64}$ M.J. Zimmer-Gembeck, J. Siebenbruner, W.A. Collins, A prospective study of intraindividual and peer influences on adolescents' heterosexual romantic and sexual behavior, Archives of Sexual Behavior, 2004, 33, 381.

${ }^{65}$ B.R. Karney i in., Adolescent Romantic Relationships, s. 59.

${ }^{66}$ D. Kirby, G. Lepore, J. Ryan, Sexual Risk and Protective Factors. Factors Affecting Teen Sexual Behavior, Pregnancy, Childbearing and Sexually Transmitted Disease: Which Are Important? Which Can You Change? Washington D.C. 2005, za: B.R. Karney i in., Adolescent Romantic Relationships, s. 60.

67 R.E. Sieving i in., Friends' influence on adolescents' first sexual intercourse. Perspectives on Sexual and Reproductive Health, 2006, 38, za: B.R. Karney i in., Adolescent Romantic Relationships, s. 60. 
żankami młodszymi od siebie. Dziewczęta zaś niezależnie od wieku opisują swoje relacje z partnerami starszymi od siebie ${ }^{68}$.

Wybór partnera ma też związek z wiekiem respondentów oraz etapem rozwoju związku uczuciowego. W początkowym okresie młodzież kładzie większy nacisk na powierzchowne cechy potencjalnych partnerów, a dopiero później bardziej skupiają się na przyszłych planach i wzajemności uczuć69. J. Connolly i A. Goldberg70 twierdzą, że romantyczne relacje młodszych nastolatków charakteryzuje przede wszystkim koncentracja na atrakcyjności fizycznej, jednak zmienia się to w późniejszych latach, kiedy intymność i zaangażowanie stają się szczególnie ważne. Bycie w związku, zwłaszcza kiedy partner jest popularny i pożądany przyczynia się do uzyskania wyższego statusu w grupie rówieśniczej. Należy zauważyć, że $\mathrm{w}$ dwóch początkowych fazach rozwoju romantycznych relacji rówieśnicy sprawują silną kontrolę nad zachowaniami zainteresowanych sobą osób i bardzo ważna jest dla nich akceptacja grupy ${ }^{71}$.

Istotna jest wiedza na temat zachowań, jakie podejmują adolescenci będąc w związkach uczuciowych. Bez informacji o tym, ile czasu młodzież spędza ze sobą, jakie aktywności podejmuje wspólnie, a które osobno, trudno określić funkcję, jaką pełnią te relacje także w perspektywie dalszego rozwoju. W.A. Collins ${ }^{72}$ zauważa, że to czy adolescenci są aktywni seksualnie jest mniej ważne $\mathrm{w}$ prognozowaniu długoterminowych konsekwencji, niż wiedza o tym, że para współżyje wyłącznie ze sobą.

W badaniu Add-Health Wave II, w celu poznania myśli, emocji, rodzajów i czasu poświęconego na różnorodne aktywności czy zachowania adolescentów poproszono, aby respondenci przypomnieli sobie ich ostatnią uczuciową relację i odpowiedzieli na przygotowane przez badaczy pytania. Okazało się, że $81 \%$ młodzieży zaangażowanej w romantyczną relację uważało się za „parę", $67 \%$ wychodziło tylko we dwójkę, $68 \%$ powiedziało swoim partnerom, że ich kocha, $62 \%$ dało sobie prezenty, a $49 \%$ spędzało mniej czasu z przyjaciółmi na rzecz przebywania z partnerem.

68 B.R. Karney i in., Adolescent Romantic Relationships, s. 24.

${ }^{69}$ K.M. Galotti, S.F. Kozberg, D. Applemana, Younger and older adolescents' thinking about commitments, Journal of Experimental Child Psychology, 1990, 50; B. Roscoe, M.S. Diana, R.H. Brooks, Early, middle, and late adolescents' views on dating and factors influencing partner selection, Adolescence, 1987, 22, 59-68, 1987, za: B.R. Karney i in., Adolescent Romantic Relationships, s. 14.

$70 \mathrm{~J}$. Connolly, A. Goldberg, Romantic relationships in adolescence: The role of friends and peers in their emergence and development, [w:] The development of romantic relationship in adolescence, red. W. Furman, B. Browns, C. Feiring, New York 1999.

${ }^{71}$ S. Shulman, I. Seiffge-Krenke, Adolescent romance, s. 418-420.

72 W.A. Collins, More than Myth, s. 10. 
Płeć oraz wiek mają zróżnicowany wpływ na częstotliwość przejawianych zachowań. Dziewczęta częściej niż chłopcy, a także starsi nastolatkowie $\mathrm{w}$ porównaniu z młodszymi kolegami deklarowali swoje zaangażowanie $\mathrm{w}$ okazywaniu przywiązania i zażyłości ${ }^{73}$. Wraz $\mathrm{z}$ wiekiem młodzi ludzie nabywają też więcej doświadczeń związanych z randkowaniem, byli już zakochani kilka razy, osiągają wyższe wyniki na skali namiętności, intymności czy przywiązania, ale też $w$ mniejszym stopniu idealizują romantyczne relacje $\mathrm{e}^{74}$.

Jakość romantycznej relacji odnosi się do stopnia, do jakiego partnerzy doświadczają korzyści i odczuwają satysfakcję. Wykazano, że otrzymywanie wsparcia oraz intymność w związku wiąże się z dobrym funkcjonowaniem i samopoczuciem osób zaangażowanych $\mathrm{w}$ relację, w przeciwieństwie do sytuacji, kiedy para doświadcza trudności ${ }^{75}$. Na podstawie wyników badań zauważono, że jakość relacji w okresie adolescencji różnicuje późniejsze rezultaty związku w dorosłości, np. w zakresie przywiązania ${ }^{76}$. Co ciekawe, respondenci rozumieją co oznacza zdrowa relacja i co się na nią składa. Jest też ona silnie pożądana przez adolescentów, ale mają niskie oczekiwania, czy kiedykolwiek nawiążą taką więź. Zdają sobie również sprawę, że ich aktualne związki mogą różnić się od tych, jakie prezentują ich rodzice czy inni dorośli. Badanie było jednak przeprowadzone na niewielkiej grupie 52 osób uczestniczących w wywiadzie fokusowym, co ogranicza uogólnienie

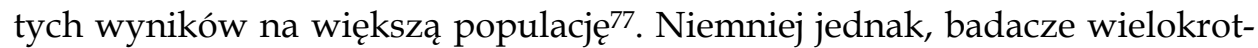
nie podkreślają różnice pomiędzy doświadczeniami młodzieży i osób dorosłych, co jest uzasadniane sekwencyjnością rozwoju tych relacji w kierunku czynienia ich bardziej dojrzałymi.

73 P.C. Giordano, W.D. Manning, M.A. Longmore, The romantic relationships of AfricanAmerican and white adolescents, Sociological Quarterly, 2005, 46, za: B.R. Karney i in., Adolescent Romantic Relationships, s. 21.

${ }_{74}$ M.J. Montgomery, Psychosocial intimacy and identity: From early adolescence to emerging adulthood, Journal of Adolescent Research, 2005, 20, za: B.R. Karney i in., Adolescent Romantic Relationships, s. 21.

75 W.A. Collins, More than Myth, s. 11.

${ }_{76}$ R.J. Levesque, The romantic experience of adolescents in satisfying love relationships, Journal of Youth and Adolescence, 1993, 22, za: B.R. Karney i in., Adolescent Romantic Relationships, s. 61; I. Seiffge-Krenke, J. Lang, Forming and maintaining romantic relations from early adolescence to young adulthood: Evidence of a developmental sequence, [w:] Antecedents of the Quality and Stability of Adolescent Romantic Relationships, red. S. Shulman, I. Seiffge-Krenke, New Orleans, LA. 2002, za: W.A. Collins, More than Myth, s. 11.

77 L. Guzman i in., Telling It Like It Is: Teen Perspectives on Romantic Relationships, Childs Trends, 2009, 44. s. 5-6. 
B.B. Brown ${ }^{78}$ zaproponował następującą kolejność faz rozwoju relacji uczuciowych: inicjacji (ang. initiation phase), partnerstwa (affiliative phase), romantycznych relacji (romantic relationship) i zaangażowanych relacji (committed relationship). Pierwszy etap charakteryzuje koncentracja na fizycznej atrakcyjności i pragnienie przebywania z tą szczególną osobą, z którą najczęściej kontakt jest ograniczony i okazjonalny. Podstawowym celem jest wówczas poszerzenie koncepcji siebie i zdobycie pewności co do umiejętności nawiązania romantycznej relacji z potencjalnym partnerem. W rezultacie młodzież często martwi się o to, jakich doświadcza emocji, jakie podejmuje działania i w jakim stopniu jej zachowanie jest akceptowane przez rówieśników. Adolescenci proszą swoich przyjaciół o radę, w jaki sposób zwrócić na siebie uwagę osoby, która ich zainteresowała, co potwierdza rolę rówieśników w rozwoju romantycznych relacji. Komiczne zachowanie, robienie sobie żartów lub próby niewerbalnego okazywania swojej sympatii, to sposoby wykorzystywane do tego, aby zostać zauważonym. Faza inicjacji dotyczy najczęściej osób w wieku 14 lat i według badań około $20 \%$ nastolatków ma w tym wieku chłopaka lub dziewczynę. W kolejnej fazie chłopcy i dziewczęta spotykają się w mieszanych grupach. Potrzeba współdziałania, towarzystwa dominuje nad potrzebą intymności ${ }^{79}$. Respondenci biorący udział w badaniu S. Shulmana i O. Kipnisa ${ }^{80}$ opisywali retrospektywnie swoje doświadczenia w wieku 15 i 16 lat właśnie w kategorii zauroczenia, fascynacji, wspólnego przebywania i podejmowania działań oraz przyjemności, jaką wówczas odczuwali, dzięki czemu te znajomości dalej się rozwijały. Badani zauważyli, że nawiązane relacje w późniejszym czasie (prawie 10 lat później) są bardziej satysfakcjonujące, dojrzalsze i emocjonalnie bliższe, rzadziej też doświadczają problemów w związku. Potwierdzają to również wyniki polskich badań - związki preintymne charakteryzują się mniejszą skłonnością do poświęceń i troski o partnera, bardziej cenione są sympatyczne relacje (miłe spędzenie czasu) niż stabilizacja i bezpieczeństwo lub wsparcie partnera $\mathrm{w}$ realizacji celów osobistych. Także poziom wzajemnej akceptacji, szerokość i głębokość ujawniania się młodszych adolescentów jest niższy niż u osób w okresie późnej adolescencji i wczesnej dorosłości ${ }^{81}$.

${ }^{78}$ B.B. Brown, "You're going out with who?" Peer group influences on adolescent romantic relationships, [w:] The Development of Romantic Relationships in Adolescence, red. W. Furman, B.B. Brown, C. Feiring, New York 1999.

${ }^{79}$ S. Shulman, I. Seiffge-Krenke, Adolescent romance, s. 418-419.

${ }^{80}$ S. Shulman, O. Kipnis, Adolescent romantic relationships: a look from the future, Journal of Adolescence, 2001, 24, s. 341-346.

${ }^{81}$ A. Dylak, Związki intymne a tożsamość psychospołeczna w okresie dorostości, [w:] Szanse i zagrożenia rozwoju w okresie dorostości, red. A. Brzezińska, K. Appelt, J. Wojciechowska, Poznań 
Po okresie wspólnego przebywania i podejmowania wspólnych aktywności zmniejsza się rola rówieśników $\mathrm{w}$ organizacji i kontroli relacji pomiędzy zainteresowanymi sobą nastolatkami. Adolescenci kładą większy nacisk na romantyczną relację pomiędzy nimi, doświadczają wspólnie głębszych uczuć, mogą angażować się w bardziej intensywne zachowania seksualne. Wiąże się to z częstszym spędzaniem czasu tylko we dwoje, rozwojem poczucia autonomii, uniezależnienia się od grupy. W czwartej fazie (najczęściej w okresie późnego dorastania) relacje stają się długotrwałe, nie bazują tylko na atrakcyjności, ale także na zdolności do przejawiania zachowań opiekuńczych wobec partnera. Do pewnego zakresu nawiązane relacje przypominają te małżeńskie. Takie relacje badane są pod względem poziomu intymności w związku ${ }^{82}$. W badań, które zostały przeprowadzone w Polsce na grupie 42 młodych dorosłych badano właściwości związków preintymnych, które są typowe dla adolescentów i relacji intymnych, które nawiązują osoby w okresie wczesnej dorosłości. Zauważono, że poziom bliskości, zdolność do poświęceń, akceptacja, troska i możliwości rozwoju osobistego był wyższy w przypadku relacji trwających w okresie wczesnej dorosłości. Co więcej, wykazano, że związki intymne są powiązane z tożsamością psychospołeczną, natomiast związki preintymne nie wykazują takiej zależności. Autorka badań uważa, że tych dwóch typów relacji nie można porównywać i rozpatrywać na jednym kontinuum - większego lub mniejszego poziomu intymności. Dodaje, że związki tworzone w jednym i drugim okresie, jeżeli mają dobrze spełnić swoje "rozwojowe" zadanie, powinny charakteryzować się odmiennymi właściwościami ${ }^{83}$.

$\mathrm{W}$ ciągu tych lat młodzieńczych bliskość przechodzi z relacji rodzicdziecko do relacji z rówieśnikami w formie przyjaźni, a później romantycznej relacji. Jednak charakter bliskości się zmienia; ogólne odczuwanie bliskości przez adolescentów zapowiada jej złożoność w późniejszym rozwoju relacji. Młodzi ludzie w większości deklarują, że ich obecna relacja uczuciowa jest tą najbliższą, $\mathrm{w}$ okresie późnej adolescencji romantyczna relacja przewyższa nawiązane przyjaźnie czy relacje dziecka z matką pod względem uczucia, intymności, towarzystwa i wsparcia. W efekcie zmiany w bliskości przemieniają powstające romantyczne relacje $\mathrm{w}$ podobne do tych nawiązy-

2002; M. Wasiak, Cechy charakterystyczne zwiazków intymnych w późnej adolescencji oraz wczesnej dorosłości, Wrocław 2010, za: A. Oleszkowicz, A. Senejko, Psychologia dorastania, s. 200-201.

82 S. Shulman, I. Seiffge-Krenke, Adolescent romance, s. 418-420.

83 A. Pindur, Intymność a tożsamość psychospołeczna: rozważania, badania, implikacje, [w:] Szanse i zagrożenia rozwoju, s. 256-257. 
wanych przez dorosłych i jednocześnie poprzedzają równoległe zmiany w orientacji na wspólne, a nie tylko indywidualne cele ${ }^{84}$.

Procesy emocjonalne i poznawcze są nierozerwanie związane $\mathrm{z}$ romantyczną relacją i odgrywają znaczącą rolę $\mathrm{w}$ określaniu ich funkcjonalnego znaczenia. Interesujące dla badaczy są m.in.: myśli, emocje, atrybucje, style wyjaśniania, schematy, oczekiwania, czy reprezentacje dotyczące związków uczuciowych ${ }^{85}$.

Relacje adolescentów zmieniają się i ewoluują. Jest to trudny czas uniezależnienia się od rodziców, ale także równoważenia wpływu rówieśników i negocjowania z partnerem. Nastolatek może doświadczać bardzo intensywnych uczuć, zarówno tych przyjemnych jak i tych trudnych, ponieważ samo bycie $w$ romantycznej relacji może być stresujące. Co więcej, mogą pojawić się napięcia $\mathrm{w}$ stosunkach $\mathrm{z}$ rówieśnikami i $\mathrm{w}$ relacji $\mathrm{z}$ rodzicami. T. Nieder i I. Seiffge-Krenke ${ }^{86}$ zbadali rodzaj stresu, jaki odczuwają nastolatkowie $\mathrm{w}$ początkowych etapach rozwoju związku i zauważyli, że osoby $\mathrm{w}$ początkowym okresie dojrzewania doświadczają wysokiego poziomu stresu przy jednocześnie niskim poziomie intymności i uczuć. Adolescent może też doświadczać złości, gniewu i zazdrości ze strony swoich znajomych, którzy mogą czuć się także zaniedbywani i wykluczeni. Im respondenci byli starsi, tym częściej deklarowali niższy poziom stresu i potrafili radzić sobie $\mathrm{z}$ nim bardziej efektywnie zarówno $\mathrm{w}$ kontekście relacji z rówieśnikami, jak i z partnerem. Należy jednak zauważyć, że nieposiadanie chłopaka lub dziewczyny także może być źródłem odczuwanego stresu i trudnych emocji ${ }^{87}$.

Młodzi ludzie stają też przed dylematem dotyczącym zaspokajania sprzecznych potrzeb - swoich własnych i innych osób. Deficyty w zaspokojeniu potrzeby współzależności, która wyraża się w intymności, przynależności, seksualności, jest najczęstszą przyczyną rozstań wśród adolescentów. Kolejne powody zerwania z partnerem zostały przyporządkowane kategorii niezależności, w ramach której wyróżniono potrzebę autonomii i tożsamości. Mimo że doświadczenie rozpadu związku może być dla młodzieży trudne, to należy je traktować jako rozwojowe. Kiedy młody człowiek decyduje się zakończyć relację, to znaczy, że potrafi już zidentyfikować własne potrzeby i będzie poszukiwał osoby, z którą będzie lepiej dopasowany. Nie

84 R.E. Adams, B. Laursen, D. Wilder, Characteristic of closeness in adolescent romantic relationships, Journal of Adolescence, 2001, 24, s. 354.

85 W.A. Collins, More than Myth, s. 11-12.

86 T. Nieder, I. Seiffge-Krenke, Coping with stress in different phases of romantic development, Journal of Adolescence, 2001, 24(3).

87 S. Shulman, I. Seiffge-Krenke, Adolescent romance, s. 419, 23. 
znaczy to jednak, że rozstanie jest zawsze przejawem dojrzałości nastolatka lub partnera. Starsza młodzież jest już bardziej otwarta na możliwość długoterminowego związku, w którym zaangażowanie we wspólny cel równoważy dbałość o indywidualność 88 . Pojawiające się emocje pełnią specyficzną funkcję dla jednostki. Doświadczanie trudnych emocji może być mobilizujące do tego, aby chronić zagrożoną romantyczną więź albo ją rozwiązać. Innymi słowy, odczuwane emocje mogą być potraktowane jako mechanizm, dzięki któremu młodzi ludzie oceniają swoje relacje i podejmują decyzję o jej kontynuacji lub zakończeniu ${ }^{89}$.

\section{Zakończenie}

W niniejszym artykule postawiono następujące pytania: jaka jest rola i znaczenie związków uczuciowych adolescentów w ich dalszym rozwoju oraz jaki obraz związków uczuciowych adolescentów wyłania się na podstawie wyników dotychczas przeprowadzonych badań. $\mathrm{W}$ tym celu wykorzystano dostępne $\mathrm{w}$ bazach danych artykuły dotyczące związków uczuciowych adolescentów.

Wykazano, że zaangażowanie się w związek uczuciowy w okresie dojrzewania może różnicować realizację zadań rozwojowych przewidzianych na okres adolescencji, a także rezultaty związków uczuciowych w okresie wczesnej dorosłości. Istotne warunki poprzedzające nawiązywanie relacji uczuciowych kształtują się od momentu narodzin dziecka, ważne jest środowisko, w jakim dorasta jednostka, status społeczno-ekonomiczny rodziny, jej struktura i relacje w niej panujące, a także indywidualne różnice czy więzi z rówieśnikami. Okres dojrzewania jest kluczowy, ponieważ młody człowiek wzmacnia lub zmienia poznawcze reprezentacje dotyczące bliskich relacji uczuciowych, także pod wpływem nabywanych doświadczeń. Badacze zwracają również uwagę na konkretne zachowania podejmowane przez młodych ludzi, jak np. czas rozpoczęcia randkowania, liczba partnerów, okres trwania związku.

W.A. Collins ${ }^{90}$ zauważa, że prowadzenie badań nad związkami młodych ludzi zostało utrudnione przez przyjęcie błędnych założeń i istnieją co najmniej trzy mity na temat randkowania adolescentów. Na podstawie przy-

$88 \mathrm{~J}$. Connolly, C. McIsaac, Adolescents' explanations for romantic dissolutions: A developmental perspective, Journal of Adolescence, 2009, 32(5), s. 1209-1221.

89 R.W. Simon, D. Eder, C. Evans, The development of feeling norms underlying romantic love among adolescent females, Social Psychology Quarterly, 1992, 55, za: S. Shulman, I. SeiffgeKrenke, Adolescent romance, s. 422.

${ }^{90}$ W.A. Collins, More than Myth, s. 1-8. 
wołanych wyników badań można te błędne założenia zdemistyfikować. Po pierwsze, istniało silne przekonanie, że relacje nawiązywane przez młodzież są powierzchowne i przemijające. Należy jednak zauważyć, że relacje uczuciowe adolescentów są ważne $\mathrm{w}$ aspekcie ich psychospołecznego funkcjonowania $\mathrm{w}$ okresie dorastania, a także $\mathrm{w}$ perspektywie długofalowych rezultatów. Po drugie, twierdzono, że romantyczne relacje osób w okresie dorastania odzwierciedlają jedynie wpływ innych, bardziej dostępnych systemów społecznych. Obecnie przyjmuje się, że związki uczuciowe pojawiają się w innym kontekście niż relacje z rodzicami czy przyjaciółmi. Nadal prowadzone są badania dotyczące analizy więzi dziecka z osobami znaczącymi, ale zauważono, że na ich podstawie nie da się całkowicie wyjaśnić i przewidzieć rezultatów romantycznych związków w późniejszych latach. Po trzecie, prowadzono badania dotyczące romantycznych związków, ponieważ na ich podstawie próbowano prognozować niedostosowanie. Jednak to, czy relacje uczuciowe mogą być połączone z zachowaniami ryzykownymi zależy od specyficznych właściwości romantycznych zachowań i doświadczeń.

Z zaprezentowanych wyników badań wynika również, że związki uczuciowe adolescentów charakteryzuje zmienność i dynamizm. Obraz tych relacji różni się zależnie od tego, czy związek uczuciowy został nawiązany przez osoby w okresie wczesnej lub późnej adolescencji. Ta właściwość przejawia się w każdej z analizowanych kategorii.

Najczęściej wykorzystywanym wskaźnikiem do opisu związków uczuciowych było ich występowanie i okres trwania. Wiedza na temat zachowań, które są podejmowane przez adolescentów zaangażowanych $\mathrm{w}$ związek uczuciowy, preferencje adolescentów co do wyboru partnera, a także ich myśli i emocje związane $\mathrm{z}$ byciem $\mathrm{w}$ związku stosunkowo rzadko stanowią przedmiot zainteresowania badaczy. Można jednak zauważyć, że z wiekiem zmieniają się kryteria oceny atrakcyjności partnera, zachowania względem niego, częstotliwość i siła odczuwanych emocji. Prowadzono także badania dotyczące jakości związków adolescentów. Porównywano relacje młodszych i starszych nastolatków oraz adolescentów i osób w okresie wczesnej dorosłości. Pojawiające się różnice interpretuje się jako przejaw rozwoju związków uczuciowych w czynieniu ich bardziej dojrzałymi. $Z$ jednej strony ten proces ujmowany jest jako pewna sekwencja etapów, podczas których młodzi ludzie kumulują swoje doświadczenia i rozwijają umiejętności. Przyjmując takie założenie, badacze analizowali np. poziom intymności, wskazując, że adolescenci uzyskują niższe wyniki w porównaniu z osobami starszymi. Według A. Pindur ${ }^{91}$, tych dwóch typów relacji nie można porównywać i rozpatrywać na jednym kontinuum - większego lub mniejszego poziomu

${ }^{91}$ A. Pindur, Intymność a tożsamość psychospołeczna, s. 256-257. 
intymności. Warto zwrócić uwagę, że w polskiej literaturze związki adolescentów są określane jako związki preintymne, natomiast relacje osób dorosłych jako związki intymne. Podobnej tendencji nie zauważono przy zapoznawaniu się z artykułami anglojęzycznymi. $Z$ drugiej strony podkreśla się nie tyle zmiany $w$ zakresie liczby doświadczeń, ale ich wzrastającą złożoność i specyficzną funkcję. Związki tworzone w jednym i drugim okresie, jeżeli mają dobrze spełnić swoje "rozwojowe” zadanie, powinny charakteryzować się odmiennymi właściwościami. Niemniej jednak pomijając rozstrzygnięcie tej kwestii, wskazane $\mathrm{w}$ artykule różnice $\mathrm{w}$ obrazie związków uczuciowych młodszych i starszych adolescentów powinny zostać uwzględnione przy projektowaniu badań dotyczących relacji nawiązywanych w różnym wieku.

\section{BIBLIOGRAFIA}

Adams R.E, Laursen B., Wilder D., Characteristic of closeness in adolescent romantic relationships, Journal of Adolescence, 2001, 24.

Albert B., With One Voice 2004: America's Adults and Teens Sound Out About Teen Pregnancy. An Annual Survey, The National Campaign to Prevent Teen Pregnancy, Washington D.C. 2004.

Anderson E., Streetwise: Race, class, and change in an urban community, University of Chicago Press, Chicago 1990.

Bearman P.S., Moody J., Stovel K., Chains of affection: The structure of adolescent romantic and sexual networks, American Journal of Sociology, 2004, 110.

Boguszewski R., Kowalczuk K., Aspiracje, dążenia i plany życiowe młodziė̇y, [w:] Młodziė̇ 2013, 2014, s. 6-21, http://www.cinn.gov.pl/portal?id=15\&res_id=673746, [dostęp: 13.11.2014].

Boguszewski R., Feliksiak M., Gwiazda M., Kalka J., Młodzież o sobie: wartości, obyczajowość, grupy odniesienia, [w:] Młodzież 2013, 2014, s. 106-153, http:/ /www.cinn.gov.pl/ portal?id=15\&res_id=673746, [dostęp: 13.11.2014].

Brown B.B., "You're going out with who?" Peer group influences on adolescent romantic relationships, [w:] The Development of Romantic Relationships in Adolescence, red. W. Furman, B.B. Brown, C. Feiring, Cambridge University Press, New York 1999.

Brown B.B., Feiring C., Furman W., Missing the love boat: why researchers have shied away from adolescent romance, [w:] The Development of Romantic Relationships in Adolescence, red. W. Furman, B.B. Brown, C. Feiring, Cambridge University Press, New York 1999.

Brzezińska A., Społeczna psychologia rozwoju, Wydawnictwo Naukowe Scholar, Warszawa 2000.

Carver K.P., Joyner K., Udry J.R., National estimates of adolescent romantic relationships, [w:] Adolescent Romantic Relations and Sexual Behavior: Theory, Research, and Practical Implications, red. P. Florsheim, Lawrence Erlbaum Associates, Mahwah, NJ 2003.

Coley R.L., Chase-Lansdale P.L., Adolescent pregnancy and parenthood: Recent evidence and future directions. American Psychologist, 1998, 53. 
Collins W.A., More than Myth: The Developmental Significance of Romantic Relationships During Adolescence, Journal of Research on Adolescence, 2003, 13(1).

Connolly J., Craig W., Goldberg A., Pepler D., Mixed-Gender Groups, Dating, and Romantic Relationships in Early Adolescence, Journal of Research on Adolescence, 2004, 14(2).

Connolly J., Goldberg A., Romantic relationships in adolescence: The role of friends and peers in their emergence and development, [w:] The development of romantic relationship in adolescence, red. W. Furman, B. Browns, C. Feiring, Cambridge University Press, New York 1999.

Connolly J., McIsaac C., Adolescents' explanations for romantic dissolutions: A developmental perspective, Journal of Adolescence, 2009, 32(5).

Cooksey E.C., Mott F.L., Neubauer S.A., Friendships and early relationships: Links to sexual initiation among American adolescents born to young mothers, Perspectives on Sexual and Reproductive Health, 2002, 34.

Dylak A., Związki intymne a tożsamość psychospołeczna w okresie dorostości, [w:] Szanse i zagrożenia rozwoju w okresie dorostości, red. A. Brzezińska, K. Appelt, J. Wojciechowska. Wydawnictwo Fundacji Humaniora, Poznań 2002.

Erikson E.H., Growth and crisis of the healthy personality, [w:] Psychological Issues, vol. 1 Identity and the Life Cycle, red. E.H. Erikson, International Universities Press, New York 1959.

Eyre S.L., Hoffman V., Millstein S.G., The gamesmanship of sex: A model based on African American adolescent accounts, Medical Anthropology Quarterly, 1998, 12.

Feiring C., Gender identity and the development of romantic relationships in adolescence, [w:] The development of romantic relationships in adolescence, red. W. Furman, B.B. Brown, C. Feiring, Cambridge University Press, Cambridge, UK 2000.

Furman W., The Emerging Field of Adolescent Romantic Relationships, Current Directions in Psychological Science, 2002, 11.

Furman W., Shaffer L., The role of romantic relationships in adolescent development, [w:] Adolescent romantic relations and sexual behavior: Theory, research, and practical implications, red. P. Florsheim, Lawrence Erlbaum Associates, Mahwah, NJ 2003.

Galotti K.M., Kozberg S.F., Appleman D., Younger and older adolescents' thinking about commitments, Journal of Experimental Child Psychology, 1990, 50.

Gavin L., Furman W., Age difference in adolescents' perceptions of their peer groups, Developmental Psychology, 1989, 25.

Giordano P.C., Manning W.D., Longmore M.A., The romantic relationships of African- American and white adolescents, Sociological Quarterly, 2005, 46.

Guzman L., Ikramullah E., Manlove J., Peterson K., Scarupa H.J., Telling It Like It Is: Teen Perspectives on Romantic Relationships, Childs Trends, 2009, 44.

Harter S., Manual for the self-perception profile for adolescents, University of Denver, Denver, CO 1988.

Izdebski Z., Seksualność Polaków na początku XXI wieku. Studium badawcze, Wydawnictwo UJ, Kraków 2012.

Karney B.R., Beckett M.K., Collins R.L., Shaw R., Adolescent Romantic Relationships as Precursors of Healthy Adult Marriages. A Review of Theory, Research, and Programs, RAND Corporation 2007.

Kirby D., Lepore G., Ryan J., Sexual Risk and Protective Factors. Factors Affecting Teen Sexual Behavior, Pregnancy, Childbearing and Sexually Transmitted Disease: Which Are Important? Which Can You Change? National Campaign to Prevent Teenage Pregnancy, Washington D.C. 2005. 
Kłym M., Cieciuch J., The Early Identity Exploration Scale - a measure of initial exploration in breadth during early adolescence, Frontiers of Psychology, 2015.

LaVoie J.C., Johnson D., Mahoney M., Ramet J., Anderson B., Boundary Determinants in Adolescent Same-sex and Cross-sex Relationships, Paper presented at the 7th Biennial Meeting of the Society for Research on Adolescence, San Diego, CA 1998.

Leaper C., Anderson K.J., Gender development and heterosexual romantic relationships during adolescence, [w:] Romantic Relationships in Adolescence: Developmental Perspectives, red. S. Shulman, W.A. Collins, Jossey-Bass, San Francisco, CA 1997.

Levesque R.J., The romantic experience of adolescents in satisfying love relationships, Journal of Youth and Adolescence, 1993, 22.

Merz E-M., Jak S., The long reach of childhood experiences influence close relationships and loneliness across life, Advances in Life Course Research, 2013, 18.

Montgomery M.J., Psychosocial intimacy and identity: From early adolescence to emerging adulthood, Journal of Adolescent Research, 2005, 20.

Newman B.M., Newman Ph.R., Development Through Life. A Psychosocial Approach, The Dorsey Press, Homewood, Ill. 1984.

Nieder T., Seiffge-Krenke I., Coping with stress in different phases of romantic development, Journal of Adolescence, 2001, 24(3).

Oleszkowicz A., Senejko A., Psychologia dorastania. Zmiany rozwojowe w dobie globalizacji, Wydawnictwo Naukowe PWN, Warszawa 2013.

Pindur A., Intymność a tożsamość psychospołeczna: rozważania, badania, implikacje, [w:] Szanse i zagrożenia rozwoju w okresie dorosłości, red. A. Brzezińska, K. Appelt, Wydawnictwo Fundacji Humaniora, Poznań 2000.

Richards M.H., Crowe P.A., Larson R., Swarr A., Developmental patterns and gender differences in the experience of peer companionship during adolescence, Child Development, $1998,69$.

Roscoe B., Diana M.S., Brooks R.H., Early, middle, and late adolescents' views on dating and factors influencing partner selection, Adolescence, 1987, 22.

Scharf M., Mayseless O., The capacity for romantic intimacy: exploring the contribution of best friend and marital and parental relationships, Journal of Adolescence, 2001, 24.

Seiffge-Krenke I., Lang J., Forming and maintaining romantic relations from early adolescence to young adulthood: Evidence of a developmental sequence, [w:] Antecedents of the Quality and Stability of Adolescent Romantic Relationships, red. S. Shulman, I. Seiffge-Krenke (współprzewodniczący), Symposium at the conference of the Society for Research on Adolescence, New Orleans, LA 2002.

Shulman S., Kipnis O., Adolescent romantic relationships: a look from the future, Journal of Adolescence, 2001, 24.

Shulman S., Seiffge-Krenke I., Adolescent romance: between experience and relationships, Journal of Adolescence, 2001, 24.

Sieving R.E., Eisenberg M.E., Pettingell S., Skay C., Friends' influence on adolescents' first sexual intercourse, Perspectives on Sexual and Reproductive Health, 2006, 38.

Simon R.W., Eder D., Evans C., The development of feeling norms underlying romantic love among adolescent females, Social Psychology Quarterly, 1992, 55.

Simpson J.A., Collins W.A., Salvatore J.E., Sung S., The impact of early interpersonal experience on adult romantic relationship functioning, [w:] Mechanisms of social connection: From brain to group, red. M. Mikulincer, P. Shaver, American Psychological Association, Washington 2014. 
Summers P., Forehand R., Armistead L., Tannenbaum L., Parental divorce during early adolescence in Caucasian families: The role of family process variables in predicting the long-term consequences for early adult psychosocial adjustment, Journal of Consulting and Clinical Psychology, 1998, 66.

Tomaszewska H., Młodzież, rówieśnicy i nowe media: społeczne funkcje technologii komunikacyjnych w życiu nastolatków, Wydawnictwo Akademickie Żak, Warszawa 2012.

Wasiak M., Cechy charakterystyczne związków intymnych w późnej adolescencji oraz wczesnej dorosłości - niepublikowana praca magisterska, Uniwersytet Wrocławski, Wrocław 2010.

Zimmer-Gembeck M.J., Siebenbruner J., Collins W.A., Diverse aspects of dating: associations with psychosocial functioning from early to middle adolescence, Journal of Adolescence, 2001, 24.

Zimmer-Gembeck M.J., Siebenbruner J., Collins W.A., A prospective study of intraindividual and peer influences on adolescents' heterosexual romantic and sexual behavior, Archives of Sexual Behavior, 2004, 33. 